\title{
Diagnostic Accuracy of the Quidel Sofia Rapid Influenza Fluorescent Immunoassay in Patients with Influenza-like illness: A Systematic Review and Meta-analysis
}

Jonghoo Lee ( $\sim$ lovlet@paran.com )

Jeju National University Hospital https://orcid.org/0000-0003-2626-7099

Jae-Uk Song

Kangbuk Samsung Hospital: Kangbuk Samsung Medical Center

\section{Research}

Keywords: Influenza, Human; Diagnosis; Point-of-Care Testing; Fluorescence Polarization Immunoassay

Posted Date: October 29th, 2020

DOI: https://doi.org/10.21203/rs.3.rs-97759/v1

License: @ (i) This work is licensed under a Creative Commons Attribution 4.0 International License. Read Full License

Version of Record: A version of this preprint was published at Tuberculosis and Respiratory Diseases on July 1st, 2021. See the published version at https://doi.org/10.4046/trd.2021.0033. 


\section{Abstract}

Background: Although the Quidel Sofia rapid influenza fluorescent immunoassay (FIA) is widely used to identify influenza A and B, the diagnostic accuracy of this test remains unclear. We compared the diagnostic performances of this test with reverse transcriptasepolymerase chain reaction.

Methods: A systematic literature search was performed using MEDLINE, EMBASE, and the Cochrane Central Register. The sensitivity, specificity, diagnostic odds ratio (DOR), and a hierarchical summary receiver-operating characteristic curve (HSROC) of this test for identifying influenza A and B were pooled using meta-analysis. A sensitivity and subgroup analysis was used to identify potential sources of heterogeneity within the selected studies.

Results: We identified seventeen studies comprising 8,334 patients. The pooled sensitivity, specificity, and DOR of the Quidel Sofia rapid influenza FIA to identify influenza A were 0.78 ( $95 \% \mathrm{Cl}, 0.71-0.83), 0.99(95 \% \mathrm{Cl}, 0.98-0.99)$, and $251.26(95 \% \mathrm{Cl}, 139.39-452.89)$, respectively. The pooled sensitivity, specificity, and diagnostic odds ratio of this test to identify influenza $\mathrm{B}$ were $0.72(95 \% \mathrm{Cl}, 0.60-0.82)$, 0.98 (95\% Cl, 0.96-0.99), and 140.20 (95\% Cl, 55.92-351.54), respectively. The area under the HSROC for this test was similar for identification of influenza A and influenza B. Age was considered a probable source of heterogeneity.

Conclusions: The pooled sensitivities of the Quidel Sofia rapid influenza FIA did not quite meet the target level ( $\geq 80 \%)$ for both influenza A and $B$. The interpretation of data should be carefully considered due to substantial between-study heterogeneity.

\section{Background}

Influenza, an acute respiratory viral infection caused by influenza A or B viruses, occurs mainly in the winter months throughout the world and causes significant morbidity and mortality worldwide [1, 2]. Adequate antiviral therapy can shorten the time of illness and reduce the duration of hospitalization and the risk of complications from influenza infection [3]. Clinical benefit of antiviral therapy is greatest when started soon after the onset of influenza illness [4]. Therefore, rapid and accurate diagnosis of influenza infection is necessary in clinical practice.

Although polymerase chain reaction (PCR) has been used as the reference standard for diagnosing viral infections, performing PCR is relatively expensive and requires technical expertise [5]. Alternatively, point-of-care rapid influenza diagnostic tests (RIDTs) detect viral antigens by immunoassay and provide quick results within 30 minutes. They can facilitate antiviral therapy, reduce additional diagnostic tests and hospitalization therapy, and induce appropriate infection control measures [6, 7]. A recent systematic review and meta-analysis for 162 diagnostic accuracy studies of RIDTs revealed that traditional RIDTs had high specificity greater than $98 \%$ but poor sensitivity (54.4\% for influenza A and 53.2\% for influenza B) [5]. Two classes of RIDTs, automated immunochromatographic antigen detection tests (digital immunoassays [DIAs]) and rapid nucleic acid amplification tests (NAATs), have been used since 2011 [5]. The pooled sensitivities for DIAs ( $80.0 \%$ for influenza A and $76.8 \%$ for influenza B) and rapid NAATs (91.6\% for influenza A and $95.4 \%$ for influenza B) are significantly higher than those for traditional RIDTs [5].

As a type of DIA, the Quidel Sofia rapid influenza fluorescent immunoassay (FIA) (Quidel Corporation, CA, USA) is a point-of-care test to detect influenza $A$ and $B$ in less than 15 minutes using a compact instrument (Sofia Analyzer). Although the performance characteristics of this test to detect seasonal influenza virus strains have been established, the diagnostic accuracy of the Quidel Sofia rapid influenza FIA is not yet fully known.

\section{Methods}

\section{Data Sources and Search Strategy}

Based on a systematic review and meta-analysis of clinical trial data, we investigated the diagnostic properties of the Quidel Sofia rapid influenza FIA in patients with influenza like illness. This meta-analysis is reported in accordance with the Preferred Reporting Items for Systematic reviews and Meta-Analyses of Diagnostic Test Accuracy Studies statement [8]. We performed a comprehensive search of three electronic databases (MEDLINE, EMBASE, and the Cochrane Central Register) up to July, 2020. Search terms for influenza included:

"Influenza, Human" [MeSh] OR "Influenza A virus" OR "Influenza B virus" OR "influenza" OR "flu”. Search terms for the tests included: "rapid test*" OR "rapid diagnos*” OR "point-of-care test*" OR "immunoassay*” OR "immunochromatographic test*" OR "influenza FIA" OR "Quidel Sofia Influenza" OR "Rapid Detection Flu". As this study was a systematic review of published articles, neither informed consent nor ethics approval was required. We also conducted a manual search of the references listed in relevant review articles. 


\section{Study selection}

We included studies that met the following inclusion criteria: (1) full-length reports published in peer-reviewed English language journals; (2) evaluated the performance of the Quidel Sofia rapid influenza FIA, compared to a reference standard; (3) included patients with influenza-like illness; and (4) provided sufficient data to calculate absolute numbers of true-positive, false-positive, false-negative, and truenegative results. Review articles, case reports, commentaries, and studies reporting outcomes without raw data or peer review were excluded. Participant demographics and underlying diseases were not restricted.

Influenza-like illness was defined as fever $\geq 38^{\circ} \mathrm{C}$ and any signs/symptoms of respiratory tract infection (e.g., cough, sputum, sore throat, wheezing, etc.). We allowed the followings as specimens; nasopharyngeal aspirates, swabs, or washes; nasal aspirates, swabs, or washes; and throat swabs. A reference standard was either a commercial or laboratory-developed reverse transcriptase-polymerase chain reaction (RT-PCR).

\section{Data Extraction and Quality Assessment}

J-U.S. and J.L. independently performed extraction of potentially relevant studies and reviewed each study according to predefined eligibility criteria, after which data were extracted. Any disagreements that arose during the process of study selection or data extraction were resolved by discussion. A predefined form was used to extract data from each study. The following data from each study included in the meta-analysis were extracted: author, year of publication, study design, place of study, number of participants, age, gender, study period, type of reference standard, type of specimens, and type of population. As recommended by the Cochrane Collaboration, we used the Quality Assessment of Diagnostic Accuracy Studies (QUADAS)-2 tool to assess the risk of bias in diagnostic test accuracy [9]. Discrepancies were resolved by consensus between the two authors (J-U.S. and J.L.).

\section{Data Synthesis and Statistical Analysis}

For diagnostic meta-analysis, we used random effects meta-analyses to generate pooled estimates with $95 \%$ confidence intervals (Cls). We extracted the numbers of patients with true-positive, false-positive, false-negative, and true negative test results either directly or through a recalculation based on the reported measures of accuracy in combination with the prevalence and sample size of the included study. We calculated the pooled sensitivity and specificity, positive likelihood ratio (PLR), negative likelihood ratio (NLR), diagnostic odds ratio (DOR), and area under the receiver-operating characteristic curve (AUC) as pooled estimates with a 95\% confidence interval (CI) [10]. We also constructed hierarchical summary receiver-operating characteristic curves (HSROCs). To assess the effect of potential sources of heterogeneity, we added the following covariates to the model: study design (single vs. multicenter), number of participants ( $\geq 250 \mathrm{vs.}$ $<250$ ), study period (influenza vs. non-specific season), reference standard (RT-PCR only vs. RT-PCR and virus culture), and study population (children vs. adult). We calculated pooled sensitivity and specificity estimates for each covariate. To investigate the effect of study quality, we performed sensitivity analyses. A $P$ value $<0.05$ was considered statistically significant. Statistical analyses were performed with Stata statistical software (Version 14.2, Stata Corp LP, College Station, TX, USA), and Review Manager (Version 5.3, Nordic Cochrane Centre, The Cochrane Collaboration, Copenhagen, Denmark).

\section{Results}

\section{Study search and characteristics and quality of included studies}

The literature search process is shown in Fig. 1. We initially identified 432 articles from Pubmed, 1,310 articles from EMBASE, and 356 articles from the Cochrane library, and an additional article from hand-searching. After removing duplicate articles, we screened 1,664 potentially eligible articles. After reviewing the title and abstracts, 1,629 search records were removed, and the remaining 35 articles were eligible for reading the full text. Fifteen articles were excluded for the reasons shown in Fig. 1. With quantitative synthesis, seventeen studies were included in our final analysis [11-27].

Table 1 summarizes the features of the included studies. For influenza A, we identified seventeen studies comprising 8,334 participants. For influenza B, sixteen studies involving 7,909 subjects met the defined inclusion criteria. One study assessed influenza A infection only [21]. The number of patients in each trial ranged from 68 to 1,649. All studies were published between 2012 and 2018. Most of the studies evaluated combined populations of adults and children. Two studies included virus culture with RT-PCR as reference standards $[18,26]$. From the QUADAS assessment, the quality of the included studies was deemed satisfactory as a whole. 
Table 1

Characteristics of the studies included in the meta-analysis

\begin{tabular}{|c|c|c|c|c|c|c|c|c|c|}
\hline Study, year & Design & Country & $\begin{array}{l}\text { Number of } \\
\text { participants }\end{array}$ & $\begin{array}{l}\text { Age, } \\
\text { years } \\
\text { (mean } \\
\text { or } \\
\text { median) }\end{array}$ & $\begin{array}{l}\text { Male } \\
(\%)\end{array}$ & $\begin{array}{l}\text { Study } \\
\text { period }\end{array}$ & $\begin{array}{l}\text { Reference } \\
\text { standard }\end{array}$ & $\begin{array}{l}\text { Type of } \\
\text { specimens }\end{array}$ & Population \\
\hline $\begin{array}{l}\text { Bruning, } 2014 \\
\text { [11] }\end{array}$ & $\begin{array}{l}\text { Single- } \\
\text { center } \\
\text { study }\end{array}$ & Netherlands & 68 & NA & NA & $\begin{array}{l}\text { December } \\
2013 \text { to } \\
\text { February } \\
2014\end{array}$ & RT-PCR & $\begin{array}{l}\text { NP swabs } \\
\text { or } \\
\text { aspirates }\end{array}$ & $\begin{array}{l}\text { Children } \\
\text { (aged 0- } \\
16 \text { years old) } \\
\text { with } \\
\text { symptoms of } \\
\text { respiratory } \\
\text { illness } \\
\text { admitted to } \\
\text { either } \\
\text { pediatric ICU } \\
\text { or infant } \\
\text { ward }\end{array}$ \\
\hline $\begin{array}{l}\text { Busson, } 2017 \\
\text { [12] }\end{array}$ & $\begin{array}{l}\text { Multi- } \\
\text { center } \\
\text { study }\end{array}$ & Belgium & 267 & 3.5 & 46.6 & $\begin{array}{l}\text { January } \\
2015 \text { to } \\
\text { March } \\
2015\end{array}$ & RT-PCR & $\begin{array}{l}\text { NP swabs, } \\
\text { NP } \\
\text { aspirates, } \\
\text { broncho- } \\
\text { alveolar } \\
\text { lavages }\end{array}$ & $\begin{array}{l}\text { Children and } \\
\text { adult } \\
\text { patients } \\
\text { admitted } \\
\text { with } \\
\text { suspected } \\
\text { influenza }\end{array}$ \\
\hline $\begin{array}{l}\text { Dunn, } 2014 \\
\text { [13] }\end{array}$ & $\begin{array}{l}\text { Single } \\
\text { center } \\
\text { study }\end{array}$ & USA & 240 & NA & NA & $\begin{array}{l}\text { January } \\
2013 \text { to } \\
\text { April } 2013\end{array}$ & RT-PCR & $\begin{array}{l}\text { Nasal } \\
\text { wash }\end{array}$ & $\begin{array}{l}\text { Symptomatic } \\
\text { patients } \\
\text { under } \\
18 \text { years of } \\
\text { age }\end{array}$ \\
\hline $\begin{array}{l}\text { Gomez, } 2016 \\
\text { [14] }\end{array}$ & $\begin{array}{l}\text { Single } \\
\text { center } \\
\text { study }\end{array}$ & Spain & 1065 & NA & NA & $\begin{array}{l}\text { November } \\
2013 \text { to } \\
\text { April } 2014\end{array}$ & RT-PCR & $\begin{array}{l}\text { NP swabs, } \\
\text { NP } \\
\text { aspirates }\end{array}$ & $\begin{array}{l}\text { Adult (80.6\%) } \\
\text { and pediatric } \\
\text { (19.4\%) } \\
\text { patients with } \\
\text { respiratory } \\
\text { tract } \\
\text { symptoms } \\
\text { hospitalized }\end{array}$ \\
\hline $\begin{array}{l}\text { Hazelton, } \\
2015 \text { [15] }\end{array}$ & $\begin{array}{l}\text { Single } \\
\text { center } \\
\text { study }\end{array}$ & Australia & 202 & 56 & NA & NA & RT-PCR & NP swabs & $\begin{array}{l}\text { Patients } \geq \\
16 \text { years old } \\
\text { with an } \\
\text { influenza-like } \\
\text { illness }\end{array}$ \\
\hline $\begin{array}{l}\text { Hazelton, } \\
2015 \text { [16] }\end{array}$ & $\begin{array}{l}\text { Single } \\
\text { center } \\
\text { study }\end{array}$ & Australia & 209 & 56 & NA & NA & RT-PCR & $\begin{array}{l}\text { Throat } \\
\text { swabs, NP } \\
\text { swabs, or } \\
\text { nose } \\
\text { swabs }\end{array}$ & $\begin{array}{l}\text { Patients with } \\
\text { an influenza- } \\
\text { like illness }\end{array}$ \\
\hline $\begin{array}{l}\text { Kammerer, } \\
2016 \text { [17] }\end{array}$ & $\begin{array}{l}\text { Multi- } \\
\text { center } \\
\text { study }\end{array}$ & USA & 871 & NA & NA & $\begin{array}{l}2012 \text { to } \\
2014\end{array}$ & RT-PCR & $\begin{array}{l}\text { Nasal } \\
\text { swabs }\end{array}$ & $\begin{array}{l}\text { Patients with } \\
\text { an influenza- } \\
\text { like illness (> } \\
70 \% \text { of } \\
\text { patients were } \\
\text { under the } \\
\text { age of } \\
25 \text { years) }\end{array}$ \\
\hline Lee, 2012 [18] & $\begin{array}{l}\text { Single } \\
\text { center } \\
\text { study }\end{array}$ & $\begin{array}{l}\text { South } \\
\text { Korea }\end{array}$ & 169 & 27.7 & 56.4 & $\begin{array}{l}\text { December } \\
2011 \text { to } \\
\text { February } \\
2012\end{array}$ & $\begin{array}{l}\text { RT-PCR } \\
\text { and virus } \\
\text { culture }\end{array}$ & NP swabs & $\begin{array}{l}\text { Patients with } \\
\text { an influenza- } \\
\text { like illness }\end{array}$ \\
\hline
\end{tabular}




\begin{tabular}{|c|c|c|c|c|c|c|c|c|c|}
\hline Study, year & Design & Country & $\begin{array}{l}\text { Number of } \\
\text { participants }\end{array}$ & $\begin{array}{l}\text { Age, } \\
\text { years } \\
\text { (mean } \\
\text { or } \\
\text { median) }\end{array}$ & $\begin{array}{l}\text { Male } \\
\text { (\%) }\end{array}$ & $\begin{array}{l}\text { Study } \\
\text { period }\end{array}$ & $\begin{array}{l}\text { Reference } \\
\text { standard }\end{array}$ & $\begin{array}{l}\text { Type of } \\
\text { specimens }\end{array}$ & Population \\
\hline $\begin{array}{l}\text { Leonardi, } 2016 \\
\text { [19] }\end{array}$ & $\begin{array}{l}\text { Single } \\
\text { center } \\
\text { study }\end{array}$ & USA & 141 & NA & NA & $\begin{array}{l}\text { Influenza } \\
\text { seasons } \\
\text { from } 2006 \\
\text { to } 2011 \\
\text { and the } \\
2011- \\
2012\end{array}$ & RT-PCR & NP swabs & $\begin{array}{l}\text { Frozen } \\
\text { original } \\
\text { influenza- } \\
\text { positive } \\
\text { specimens } \\
\text { and } \\
\text { prospective } \\
\text { specimens }\end{array}$ \\
\hline $\begin{array}{l}\text { Lewandrowski, } \\
2013 \text { [20] }\end{array}$ & $\begin{array}{l}\text { Multi- } \\
\text { center } \\
\text { study }\end{array}$ & USA & 2047 & NA & 52.9 & NA & $\begin{array}{l}\text { RT-PCR or } \\
\text { virus } \\
\text { culture }\end{array}$ & $\begin{array}{l}\text { Nasal } \\
\text { swabs } \\
\text { and NP } \\
\text { swabs or } \\
\text { aspirates. }\end{array}$ & $\begin{array}{l}\text { Patients with } \\
\text { an influenza- } \\
\text { like illness }\end{array}$ \\
\hline Noh, 2015 [21] & $\begin{array}{l}\text { Multi- } \\
\text { center } \\
\text { study }\end{array}$ & $\begin{array}{l}\text { South } \\
\text { Korea }\end{array}$ & 391 & 40 & 37.6 & $\begin{array}{l}\text { December } \\
2012 \text { to } \\
\text { April } 2013\end{array}$ & RT-PCR & NP swabs & $\begin{array}{l}\text { Adult } \\
\text { patients with } \\
\text { influenza-like } \\
\text { illness }\end{array}$ \\
\hline Ryu, 2016 [22] & $\begin{array}{l}\text { Single } \\
\text { center } \\
\text { study }\end{array}$ & $\begin{array}{l}\text { South } \\
\text { Korea }\end{array}$ & 314 & 30.4 & 51.9 & $\begin{array}{l}\text { January } \\
2014 \text { to } \\
\text { February } \\
2015\end{array}$ & RT-PCR & NP swabs & $\begin{array}{l}\text { Patients } \\
\text { showing } \\
\text { influenza-like } \\
\text { symptoms }\end{array}$ \\
\hline Ryu, 2018 [23] & $\begin{array}{l}\text { Single } \\
\text { center } \\
\text { study }\end{array}$ & $\begin{array}{l}\text { South } \\
\text { Korea }\end{array}$ & 158 & NA & NA & 2016 & RT-PCR & NP swabs & $\begin{array}{l}\text { Patients with } \\
\text { an influenza- } \\
\text { like illness } \\
\text { between } \\
\text { neonates } \\
\text { and } 90 \text { years } \\
\text { old }\end{array}$ \\
\hline $\begin{array}{l}\text { Selove, } 2016 \\
\text { [24] }\end{array}$ & $\begin{array}{l}\text { Single } \\
\text { center } \\
\text { study }\end{array}$ & USA & 1649 & 57 & 50 & $\begin{array}{l}\text { September } \\
2014 \text { to } \\
\text { May } 2015\end{array}$ & RT-PCR & $\begin{array}{l}\text { Nasal } \\
\text { aspirates }\end{array}$ & $\begin{array}{l}\text { Patients with } \\
\text { an influenza- } \\
\text { like illness }\end{array}$ \\
\hline $\begin{array}{l}\text { Tuttle, } 2015 \\
\text { [25] }\end{array}$ & $\begin{array}{l}\text { Single } \\
\text { center } \\
\text { study }\end{array}$ & Germany & 686 & $\begin{array}{l}3.5 \text { for } \\
\text { mean, } \\
1.8 \text { for } \\
\text { median }\end{array}$ & 55 & $\begin{array}{l}\text { December } \\
2012 \text { to } \\
\text { April } 2013\end{array}$ & $\begin{array}{l}\text { RT-PCR or } \\
\text { virus } \\
\text { culture }\end{array}$ & $\begin{array}{l}\text { NP or } \\
\text { nasal } \\
\text { swabs }\end{array}$ & $\begin{array}{l}\text { Patients } \\
\text { aged 0- } \\
18 \text { years with } \\
\text { an influenza- } \\
\text { like illness }\end{array}$ \\
\hline $\begin{array}{l}\text { Yang, } 2018 \\
\text { [26] }\end{array}$ & $\begin{array}{l}\text { Single } \\
\text { center } \\
\text { study }\end{array}$ & Taiwan & 109 & 38.8 & 56.9 & $\begin{array}{l}\text { January } \\
2012 \text { to } \\
\text { December } \\
2013\end{array}$ & $\begin{array}{l}\text { RT-PCR } \\
\text { and/or } \\
\text { virus } \\
\text { culture }\end{array}$ & $\begin{array}{l}\text { NP or } \\
\text { throat } \\
\text { swabs }\end{array}$ & $\begin{array}{l}\text { Patients who } \\
\text { presented at } \\
\text { out-patient } \\
\text { clinics or the } \\
\text { emergency } \\
\text { department } \\
\text { with } \\
\text { influenza-like } \\
\text { illness }\end{array}$ \\
\hline $\begin{array}{l}\text { Yoon, } 2017 \\
\text { [27] }\end{array}$ & $\begin{array}{l}\text { Single } \\
\text { center } \\
\text { study }\end{array}$ & $\begin{array}{l}\text { South } \\
\text { Korea }\end{array}$ & 385 & 46 & 46.5 & $\begin{array}{l}\text { December } \\
2014 \text { to } \\
\text { April } 2015\end{array}$ & RT-PCR & $\begin{array}{l}\text { NP swabs } \\
\text { or saliva }\end{array}$ & $\begin{array}{l}\text { Patients with } \\
\text { an influenza- } \\
\text { like illness }\end{array}$ \\
\hline
\end{tabular}

Diagnostic accuracy of the Quidel Sofia rapid influenza FIA to identify influenza $A$ and $B$

Figures 2 and 3 show paired forest plots of sensitivity and specificity of the Quidel Sofia rapid influenza FIA for detection of influenza A and B. The pooled sensitivity across studies of the Quidel Sofia rapid influenza FIA to identify influenza A was $0.78(95 \% \mathrm{Cl}, 0.71$ to 0.83$)$, and the pooled specificity was $0.99(95 \% \mathrm{Cl}, 0.98$ to 0.99$)$. The pooled PLR and NLR were $56.99(95 \% \mathrm{Cl}, 31.87$ to 101.90$)$ and $0.23(95 \% \mathrm{Cl}$, 0.18 to 0.29$)$, respectively. The DOR for influenza A was $251.26(95 \% \mathrm{Cl}, 139.39$ to 452.89$)$. 
The pooled sensitivity across studies on influenza B was 0.72 ( $95 \% \mathrm{Cl}, 0.60$ to 0.82 ), and the pooled specificity was 0.98 ( $95 \% \mathrm{Cl}$, 0.96 to 0.99). The pooled PLR and NLR were 40.08 (95\% Cl, 17.26 to 93.07) and 0.29 (95\% Cl, 0.19 to 0.42 ), respectively. The DOR for influenza B was 140.20 (95\% Cl, 55.92 to 351.54). The pooled sensitivity and specificity of the Quidel Sofia rapid influenza FIA were similar for both influenza A and B ( $p=0.341$ for sensitivity and $p=0.206$ for specificity). Figure 4 shows HSROCs for index test and indicates Fig. 4 shows HSROCs for index test and indicates that the AUCs of the Quidel Sofia rapid influenza FIA were similar between identifications of influenza $A$ and influenza $\mathrm{B}(0.96 ; 95 \% \mathrm{Cl}, 0.94-0.98$ for influenza $\mathrm{A}$ and $0.95 ; 95 \% \mathrm{Cl}, 0.92-0.96$ for influenza $\mathrm{B}$, respectively; $p=0.166)$.

\section{Subgroup analyses and sensitivity analyses for the Quidel Sofia rapid influenza FIA to identify influenza A and B}

Table 2 summarizes the results of subgroup analyses with respect to the diagnostic performance of this test. The sensitivity of the Quidel Sofia rapid influenza FIA was significantly increased when tests were performed in children $(0.86 ; 95 \% \mathrm{Cl}, 0.78-0.92$ for influenza $\mathrm{A}$ and $0.79 ; 95 \% \mathrm{Cl}, 0.71-0.85$ for influenza $\mathrm{B}$, respectively), compared with performance in adults $(0.74 ; 95 \% \mathrm{Cl}, 0.67-0.79$ for influenza $\mathrm{A}$ and $0.33 ; 95 \% \mathrm{Cl}, 0.10-0.65$ for influenza $\mathrm{B}$, respectively). 
Table 2

Subgroup analysis for the diagnostic performance of the Quidel Sofia rapid influenza fluorescent immunoassay

\begin{tabular}{|c|c|c|c|c|c|c|}
\hline & & & Sensitivity & & Specificity & \\
\hline Variable & No. of studies & No. of patients & Adjusted (95\% Cl) & $P$ value & Adjusted (95\% Cl) & $P$ value \\
\hline \multicolumn{7}{|c|}{ Studies that evaluated influenza A } \\
\hline \multicolumn{7}{|l|}{ Study design } \\
\hline Single center & 13 & 5,344 & $0.79(0.72-0.85)$ & \multirow[t]{2}{*}{0.583} & $0.99(0.98-1.00)$ & \multirow[t]{2}{*}{0.574} \\
\hline Multicenter & 4 & 2,990 & $0.75(0.63-0.87)$ & & $0.99(0.97-1.00)$ & \\
\hline \multicolumn{7}{|l|}{ Number of participants } \\
\hline$\geq 250$ & 9 & 7,038 & $0.72(0.65-0.79)$ & \multirow[t]{2}{*}{0.173} & $0.99(0.98-1.00)$ & \multirow[t]{2}{*}{0.114} \\
\hline$<250$ & 8 & 1,296 & $0.84(0.77-0.90)$ & & $0.97(0.95-0.99)$ & \\
\hline \multicolumn{7}{|l|}{ Study period } \\
\hline Influenza season & 11 & 3,784 & $0.79(0.73-0.86)$ & \multirow[t]{2}{*}{0.440} & $0.99(0.98-1.00)$ & \multirow[t]{2}{*}{0.610} \\
\hline Non-specific season & 6 & 4,550 & $0.74(0.64-0.85)$ & & $0.99(0.97-1.00)$ & \\
\hline \multicolumn{7}{|l|}{ Reference standard } \\
\hline RT-PCR & 15 & 8,056 & $0.77(0.70-0.83)$ & \multirow[t]{2}{*}{0.801} & $0.99(0.98-0.99)$ & \multirow[t]{2}{*}{0.071} \\
\hline RT-PCR and virus culture & 2 & 278 & $0.82(0.73-0.89)$ & & $0.96(0.94-0.98)$ & \\
\hline \multicolumn{7}{|l|}{ Population } \\
\hline Children & 3 & 951 & $0.86(0.78-0.92)$ & \multirow[t]{2}{*}{0.019} & $0.97(0.96-0.98)$ & \multirow[t]{2}{*}{0.332} \\
\hline Adults & 2 & 593 & $0.74(0.67-0.79)$ & & $0.97(0.94-0.98)$ & \\
\hline \multicolumn{7}{|c|}{ Studies that evaluated influenza B } \\
\hline \multicolumn{7}{|l|}{ Study design } \\
\hline Single center & 13 & 5,310 & $0.72(0.59-0.84)$ & \multirow[t]{2}{*}{0.937} & $0.98(0.97-1.00)$ & \multirow[t]{2}{*}{0.228} \\
\hline Multicenter & 3 & 2,599 & $0.73(0.48-0.97)$ & & $0.97(0.93-1.00)$ & \\
\hline \multicolumn{7}{|l|}{ Number of participants } \\
\hline$\geq 250$ & 8 & 6,690 & $0.69(0.53-0.84)$ & \multirow[t]{2}{*}{0.730} & $0.99(0.97-1.00)$ & \multirow[t]{2}{*}{0.432} \\
\hline$<250$ & 8 & 1,219 & $0.75(0.60-0.90)$ & & $0.97(0.94-1.00)$ & \\
\hline \multicolumn{7}{|l|}{ Study period } \\
\hline Influenza season & 10 & 3,372 & $0.76(0.63-0.89)$ & \multirow[t]{2}{*}{0.403} & $0.98(0.96-1.00)$ & \multirow[t]{2}{*}{1.000} \\
\hline Non-specific season & 6 & 4,537 & $0.65(0.45-0.85)$ & & $0.98(0.96-1.00)$ & \\
\hline \multicolumn{7}{|l|}{ Reference standard } \\
\hline RT-PCR & 14 & 7,632 & $0.71(0.59-0.83)$ & \multirow[t]{2}{*}{0.901} & $0.98(0.97-1.00)$ & \multirow[t]{2}{*}{0.536} \\
\hline RT-PCR and virus culture & 2 & 277 & $0.78(0.50-1.00)$ & & $0.98(0.92-1.00)$ & \\
\hline Population & & & & & & \\
\hline Children & 3 & 994 & $0.79(0.71-0.85)$ & $<0.001$ & $0.92(0.90-0.94)$ & 0.005 \\
\hline Adults & 1 & 202 & $0.33(0.10-0.65)$ & & $0.99(0.97-1.00)$ & \\
\hline
\end{tabular}

In sensitivity analysis to investigate the influence of each individual study on the overall analysis estimate, one study had a significantly different sensitivity than the other studies on influenza A [24]. After exclusion of that study [24], the pooled sensitivity across studies on influenza A was similar to that of the overall studies $(0.79,95 \% \mathrm{Cl}, 0.75$ to 0.82$)$. 


\section{Discussion}

According to a rule by the Food and Drug Administration (FDA), RIDTs for influenza A and B are required to have a sensitivity of at least $80 \%$ and a specificity of at least $95 \%$ compared to an FDA-cleared nucleic acid based-test or other currently appropriate and FDA accepted comparator methods other than a correctly performed viral culture method [28]. A recent systematic review and meta-analysis, which was searched to May 2017, compared accuracy of traditional RIDTs, rapid NAATs, and DIAs in patients with suspected influenza [5]. For diagnosis of influenza A and B, the pooled sensitivities of DIAs including the Quidel Sofia rapid influenza FIA were $80.0 \%$ and $76.8 \%$, respectively [5].

In the present study, when compared to RT-PCR, the pooled sensitivity of the Quidel Sofia rapid influenza FIA to identify influenza A and B were $78 \%$ and $72 \%$, respectively, which indicate that our findings did not quite reach the target level of sensitivity required by the FDA. Therefore, some patients with negative results on the Quidel Sofia rapid influenza FIA may still be confirmed to have an influenza infection by alternative and more sensitive diagnostic methods.

Influenza type could have an effect on the accuracy of RIDTs. A previous meta-analysis revealed that overall RIDTs had increased sensitivity for detection of influenza A compared with influenza B (64.6\% vs. 52.2\%; $p=0.05)$ [29]. Influenza A virus causes more severe disease, higher influenza-associated hospitalization, and death compared to influenza B virus [29]. More severe virulence of influenza A may cause higher viral burden, which can lead to relatively high sensitivity [19]. In the present study, although the pooled sensitivity of the Quidel Sofia rapid influenza FIA to identify influenza A tended to be higher than that for influenza B, there was no statistical difference.

The Quidel Sofia rapid influenza FIA has the advantages of providing a simple, fast, and easy method for viral testing. The pooled specificity of this tool in our study was approximately $98 \%$, above the target level for both influenza A and B. From these findings, we believe that clinicians would be able to diagnose influenza with assurance on the basis of a positive result from the Quidel Sofia rapid influenza FIA.

Large heterogeneities are commonly reported in systematic reviews of studies on diagnostic test accuracy, and substantial between-study heterogeneity among the enrolled studies was also observed in the present study [30]. Age is a probable source of heterogeneity for between-studies in the pooled estimates. In the present study, the pooled sensitivities of the Quidel Sofia rapid influenza FIA were significantly higher by approximately 12 percentage points for influenza A and 46 percentage points for influenza B in children compared to adults. The duration of influenza virus shedding is commonly measured from symptom onset to shedding cessation time, and children have been reported to have a tendency to shed the virus for a longer duration compared to adults [31]. Longer duration of influenza virus shedding in children might be associated with a higher sensitivity of this test compared to adults. However, because the number of studies that distinguish children from adults is very small, our findings should be interpreted with caution.

The sensitivity observed in one study was significantly lower than that observed in most studies [24]. In this study, an older patient population (median age 57 years) and a study protocol that did not specify the need for particular symptoms and duration of illness may have contributed to the reduced sensitivity [24]. These factors may have been affected by low virus shedding [24]. In our sensitivity analysis conducted after excluding this study [24], the pooled sensitivity of the Quidel Sofia rapid influenza FIA across studies on influenza A was slightly increased.

To the best of our knowledge, this is the first meta-analysis to investigate the Quidel Sofia rapid influenza FIA for detection of influenza. However, potential limitations of the present study should be considered when interpreting our results. First, because this present study was based on a relatively small number of trials, our results should be carefully interpreted with limited statistical power. Second, we could not make an assessment for publication bias since no reliable methods exist to investigate this issue in diagnostic test accuracy studies [32]. Third, although we used RT-PCR as the control reference for influenza diagnosis, two included studies used both RT-PCR and virus culture as reference standards. This use of dual reference standards may elicit the introduced bias due to diagnostic differences between references standards. However, for the pooled sensitivities and specificities across studies on the Quidel Sofia rapid influenza FIA to identify influenza A and B, there were no significant differences between RT-PCR and virus culture and only RT-PCR as control references. Finally, as a sample for viral diagnosis, nasopharyngeal aspirates would present with higher quality than nasopharyngeal swabs. Although we tried to investigate the diagnostic accuracy of the Quidel Sofia rapid influenza FIA according to the type of sample, we were not able to perform this analysis because of data limitations.

\section{Conclusion}


We found that the pooled sensitivities of the Quidel Sofia rapid influenza FIA were slightly below the target level prescribed by the FDA for both influenza A and B. Therefore, especially for adults, physicians should consider the possibility of false-negative results by this test.

While the pooled specificity of this test was very high for both influenza $A$ and $B$, substantial between-study heterogeneity requires careful interpretation of the data.

\section{Abbreviations}

AUC, area under the receiver-operating characteristic curve; $\mathrm{Cl}$, confidence interval; DIA, digital immunoassay; DOR, diagnostic odds ratio; FIA, fluorescent immunoassay; HSROC, hierarchical summary receiver-operating characteristic curve; NAAT, nucleic acid amplification test; NLR, negative likelihood ratio; PCR, polymerase chain reaction; PLR, positive likelihood ratio; QUADAS, the quality assessment of diagnostic accuracy studies; RIDT, rapid influenza diagnostic test; RT-PCR, reverse transcriptase-polymerase chain reaction

\section{Declarations}

\section{Acknowledgements}

Not applicable

\section{Authors' contributions}

Jae-Uk Song contributed to data acquisition, data interpretation, statistical analysis, and drafted the manuscript. Jonghoo Lee contributed to the study design, data acquisition, data interpretation, statistical analysis, writing of the manuscript, and critical revision of the manuscript.

\section{Funding}

This work was supported by a research grant from the Jeju National University Hospital Research Fund of Jeju National University in 2020.

\section{Availability of data and materials}

All data generated or analyzed during this study are included in this published article.

\section{Ethics approval and consent to participate}

Not applicable.

\section{Consent for publication}

Not applicable.

\section{Competing interests}

The authors declare that they have no competing interests.

\section{ORCID}

Jonghoo Lee http://orcid.org/0000-0003-2626-7099

Jae-Uk Song http://orcid.org/0000-0003-4597-7037

\section{References}


1. World health organization. Use of influenza rapid diagnostic tests.

https://www.who.int/influenza/resources/publications/influenza_rapid_test/en/. Accessed 12 Oct 2020.

2. Chow EJ, Rolfes MA, O'Halloran A, Alden NB, Anderson EJ, Bennett NM, et al. Respiratory and Nonrespiratory Diagnoses Associated With Influenza in Hospitalized Adults. JAMA Netw Open. 2020;3(3):e201323. https://org/10.1001/jamanetworkopen.2020.1323.

3. Atkins CY, Patel A, Taylor TH, Jr., Biggerstaff M, Merlin TL, Dulin SM, et al. Estimating effect of antiviral drug use during pandemic (H1N1) 2009 outbreak, United States. Emerg Infect Dis. 2011;17(9):1591-1598. https://org/10.3201/eid1709.110295.

4. Fry AM, Goswami D, Nahar K, Sharmin AT, Rahman M, Gubareva L, et al. Efficacy of oseltamivir treatment started within 5 days of symptom onset to reduce influenza illness duration and virus shedding in an urban setting in Bangladesh: a randomised placebocontrolled trial. Lancet Infect Dis. 2014;14(2):109-118. https://org/10.1016/S1473-3099(13)70267-6.

5. Merckx J, Wali R, Schiller I, Caya C, Gore GC, Chartrand C, et al. Diagnostic Accuracy of Novel and Traditional Rapid Tests for Influenza Infection Compared With Reverse Transcriptase Polymerase Chain Reaction: A Systematic Review and Meta-analysis. Ann Intern Med. 2017;167(6):394-409. https://doi.org/10.7326/M17-0848.

6. Benito-Fernandez J, Vazquez-Ronco MA, Morteruel-Aizkuren E, Mintegui-Raso S, Sanchez-Etxaniz J, Fernandez-Landaluce A. Impact of rapid viral testing for influenza $A$ and $B$ viruses on management of febrile infants without signs of focal infection. Pediatr Infect Dis $J$. 2006;25(12):1153-1157. https://doi.org/10.1097/01.inf.0000246826.93142.b0.

7. Bonner AB, Monroe KW, Talley LI, Klasner AE, Kimberlin DW. Impact of the rapid diagnosis of influenza on physician decision-making and patient management in the pediatric emergency department: results of a randomized, prospective, controlled trial. Pediatrics. 2003;112(2):363-367. https://doi.org/10.1542/peds.112.2.363.

8. McInnes MDF, Moher D, Thombs BD, McGrath TA, Bossuyt PM. Preferred Reporting Items for a Systematic Review and Meta-analysis of Diagnostic Test Accuracy Studies: The PRISMA-DTA Statement. JAMA. 2018;319(4):388-396. https://doi.org/10.1001/jama.2017.19163.

9. Whiting P, Rutjes AW, Reitsma JB, Bossuyt PM, Kleijnen J. The development of QUADAS: a tool for the quality assessment of studies of diagnostic accuracy included in systematic reviews. BMC Med Res Methodol. 2003;3:25. https://doi.org/10.1186/1471-2288-3-25.

10. Reitsma JB, Glas AS, Rutjes AW, Scholten RJ, Bossuyt PM, Zwinderman AH. Bivariate analysis of sensitivity and specificity produces informative summary measures in diagnostic reviews. J Clin Epidemiol. 2005;58(10):982-990. https://doi.org/10.1016/j.jclinepi.2005.02.022.

11. Bruning AH, van Dijk K, van Eijk HW, Koen G, van Woensel JB, Kruisinga FH, et al. Evaluation of a rapid antigen detection point-of-care test for respiratory syncytial virus and influenza in a pediatric hospitalized population in the Netherlands. Diagn Microbiol Infect Dis. 2014;80(4):292-293. https://doi.org/10.1016/j.diagmicrobio.2014.08.010.12.

12. Busson L, Mahadeb B, De Foor M, Vandenberg O, Hallin M, et al. Contribution of a rapid influenza diagnostic test to manage hospitalized patients with suspected influenza. Diagn Microbiol Infect Dis. 2017;87(3):238-242. https://doi.org/10.1016/j.diagmicrobio.2016.11.015.

13. Dunn J, Obuekwe J, Baun T, Rogers J, Patel T, Snow L. Prompt detection of influenza A and B viruses using the BD Veritor System Flu $A+B$, Quidel(R) Sofia(R) Influenza A+B FIA, and Alere BinaxNOW(R) Influenza A\&B compared to real-time reverse transcriptionpolymerase chain reaction (RT-PCR). Diagn Microbiol Infect Dis. 2014;79(1):10-13. https://doi.org/10.1016/j.diagmicrobio.2014.01.018.

14. Gomez S, Prieto C, Folgueira L. A prospective study to assess the diagnostic performance of the Sofia((R)) Immunoassay for Influenza and RSV detection. J Clin Virol. 2016;77:1-4. https://doi.org/10.1016/j.jcv.2016.01.018.

15. Hazelton B, Gray T, Ho J, Ratnamohan VM, Dwyer DE, Kok J. Detection of influenza A and B with the Alere i Influenza A \& B: a novel isothermal nucleic acid amplification assay. Influenza Other Respir Viruses. 2015;9(3):151-154. https://doi.org/10.1111/irv.12303.

16. Hazelton B, Nedeljkovic G, Ratnamohan VM, Dwyer DE, Kok J. Evaluation of the Sofia Influenza A + B fluorescent immunoassay for the rapid diagnosis of influenza A and B. J Med Virol. 2015;87(1):35-38. https://doi.org/10.1002/jmv.23976.

17. Kammerer PE, Radin JM, Hawksworth AW, Myers CA, Brice GT. Performance of the Quidel Sofia rapid influenza diagnostic test during the 2012-2013 and 2013-2014 influenza seasons. Influenza Other Respir Viruses. 2016;10(3):220-223. https://doi.org/10.1111/irv.12380.

18. Lee CK, Cho CH, Woo MK, Nyeck AE, Lim CS, Kim WJ. Evaluation of Sofia fluorescent immunoassay analyzer for influenza A/B virus. J Clin Virol. 2012;55(3):239-243. https://doi.org/10.1016/j.jcv.2012.07.008.

19. Leonardi GP, Wilson AM, Zuretti AR. Comparison of conventional lateral-flow assays and a new fluorescent immunoassay to detect influenza viruses. J Virol Methods. 2013;189(2):379-382. https://doi.org/10.1016/j.jviromet.2013.02.008. 
20. Lewandrowski K, Tamerius J, Menegus M, Olivo PD, Lollar R, Lee-Lewandrowski E. Detection of influenza A and B viruses with the Sofia analyzer: a novel, rapid immunofluorescence-based in vitro diagnostic device. Am J Clin Pathol. 2013;139(5):684-689. https://doi.org/10.1309/AJCP7ZTLJCP3LLMA.

21. Noh JY, Choi WS, Lee J, Kim HL, Song JY, Cheong HJ. Clinical performance of the Sofia Influenza A+B FIA in adult patients with influenza-like illness. Diagn Microbiol Infect Dis. 2015;83(2):130-2. https://doi.org/10.1016/j.diagmicrobio.2015.05.016.

22. Ryu SW, Lee JH, Kim J, Jang MA, Nam JH, Byoun MS, et al. Comparison of two new generation influenza rapid diagnostic tests with instrument-based digital readout systems for influenza virus detection. Br J Biomed Sci. 2016;73(3):115-120. https://doi.org/10.1080/09674845.2016.1189026.

23. Ryu SW, Suh IB, Ryu SM, Shin KS, Kim HS, Kim J, et al. Comparison of three rapid influenza diagnostic tests with digital readout systems and one conventional rapid influenza diagnostic test. J Clin Lab Anal. 2018;32(2):e22234. https://doi.org/ $10.1002 /$ jcla.22234.

24. Selove W, Rao LV. Performance of rapid SOFIA Influenza A+B test compared to Luminex $x$-TAG respiratory viral panel assay in the diagnosis of influenza A, B, and subtype H3. J Investig Med. 2016;64(4):905-907. https://doi.org/10.1136/jim-2016-000055.

25. Tuttle R, Weick A, Schwarz WS, Chen X, Obermeier P, Seeber L, et al. Evaluation of novel second-generation RSV and influenza rapid tests at the point of care. Diagn Microbiol Infect Dis. 2015;81(3):171-176. https://doi.org/ 10.1016/j.diagmicrobio.2014.11.013.

26. Yang JH, Huang PY, Shie SS, Yang S, Tsao KC, Wu TL, et al. Diagnostic performance of the Sofia(R) influenza A+B fluorescent immunoassay in adult outpatients in Northern Taiwan. J Med Virol. 2018;90(6):1010-1018. https://doi.org/10.1002/jmv.25043.

27. Yoon J, Yun SG, Nam J, Choi SH, Lim CS. The use of saliva specimens for detection of influenza A and B viruses by rapid influenza diagnostic tests. J Virol Methods. 2017;243:15-19. https://doi.org/10.1016/j.jviromet.2017.01.013.

28. Federal Register. Microbiology Devices; Reclassification of Influenza Virus Antigen Detection Test Systems Intended for Use Directly With Clinical Specimens. https://www.federalregister.gov/documents/2017/01/12/2017-00199/microbiology-devices-reclassificationof-influenza-virus-antigen-detection-test-systems-intended-for. Accessed 12 Oct 2020.

29. Chartrand C, Leeflang MM, Minion J, Brewer T, Pai M. Accuracy of rapid influenza diagnostic tests: a meta-analysis. Ann Intern Med. 2012;156(7):500-511. https://doi.org/10.7326/0003-4819-156-7-201204030-00403.

30. Dinnes J, Deeks J, Kirby J, Roderick P. A methodological review of how heterogeneity has been examined in systematic reviews of diagnostic test accuracy. Health Technol Assess. 2005;9(12):1-113, iii. https://doi.org/10.3310/hta9120.

31. Ng S, Lopez R, Kuan G, Gresh L, Balmaseda A, Harris E, et al. The Timeline of Influenza Virus Shedding in Children and Adults in a Household Transmission Study of Influenza in Managua, Nicaragua. Pediatr Infect Dis J. 2016;35(5):583-586. https://doi.org/10.1097/INF.0000000000001083.

32. Leeflang MM. Systematic reviews and meta-analyses of diagnostic test accuracy. Clin Microbiol Infect. 2014;20(2):105-113. https://doi.org/10.1111/1469-0691.12474.

\section{Figures}




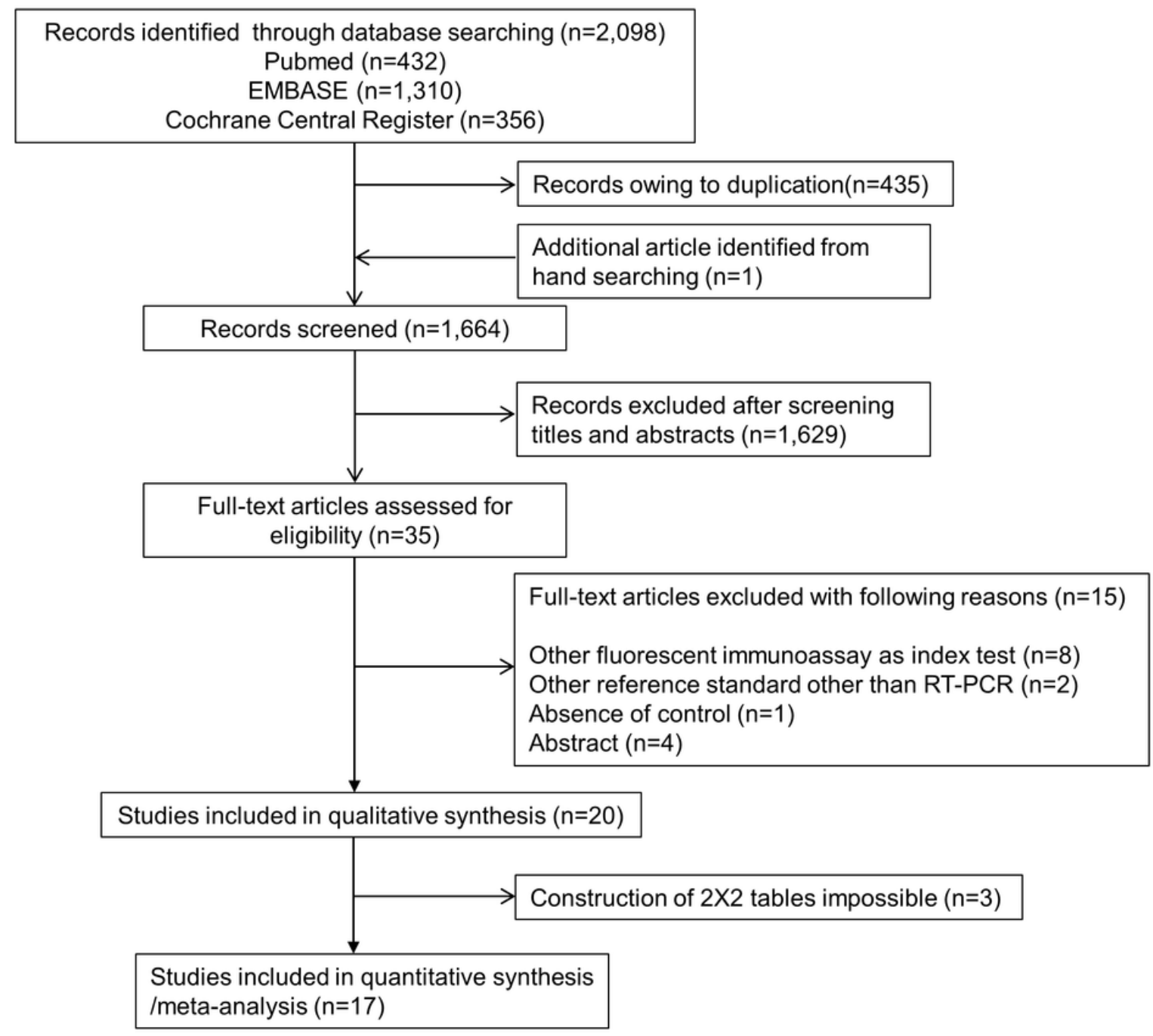

\section{Figure 1}

Flow diagram for identification of eligible studies 


\begin{tabular}{|c|c|c|c|c|}
\hline Study, year & Sensitivity $(95 \% \mathrm{Cl})$ & & Specificity $(95 \% \mathrm{Cl})$ & \\
\hline Bruning $^{11}, 2014$ & $0.67(0.30-0.93)$ &.+1 & $0.97(0.88-1.00)$ & \\
\hline Busson $^{12}, 2017$ & $0.71(0.57-0.82)$ & $\begin{array}{l}1 \\
-+\end{array}$ & $1.00(0.97-1.00)$ & -10 \\
\hline Dunn ${ }^{13}, 2014$ & $0.96(0.86-0.99)$ & $1 \rightarrow$ & $0.91(0.86-0.95)$ & $\rightarrow-1$ \\
\hline Gomez $^{14}, 2016$ & $0.75(0.70-0.80)$ & + & $0.99(0.98-0.99)$ & 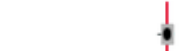 \\
\hline Hazelton $^{15}, 2015$ & $0.71(0.54-0.85)$ & $\rightarrow$ & $0.98(0.95-1.00)$ & -6 \\
\hline Hazelton $^{16}, 2015$ & $0.72(0.53-0.87)$ & $-\frac{1}{1}$ & $0.98(0.95-1.00)$ & - \\
\hline Kammerer ${ }^{17}, 2016$ & $0.76(0.69-0.83)$ & + & $0.97(0.96-0.98)$ & 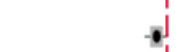 \\
\hline $\operatorname{Lee}^{18}, 2012$ & $0.82(0.71-0.90)$ & ta- & $1.00(0.96-1.00)$ & +. \\
\hline Leonardi $^{19}, 2013$ & $0.80(0.70-0.88)$ & - & $1.00(0.93-1.00)$ & 10 \\
\hline Lewandrowski ${ }^{20}, 2013$ & $0.78(0.73-0.82)$ & + & $0.99(0.99-1.00)$ & - \\
\hline $\mathrm{Noh}^{21}, 2015$ & $0.74(0.67-0.80)$ & $\underset{-1}{1}$ & $0.95(0.91-0.98)$ & $\rightarrow-1$ \\
\hline $\mathrm{Ryu}^{22}, 2016$ & $0.74(0.64-0.83)$ & -1 & $1.00(0.98-1.00)$ & 1 \\
\hline $\mathrm{Ryu}^{23}, 2017$ & $0.95(0.87-0.98)$ & $i$ & $0.98(0.92-1.00)$ & $\rightarrow$ \\
\hline Selove ${ }^{24}, 2016$ & $0.42(0.35-0.48)$ & $\begin{array}{l}-1 \\
-\quad 1\end{array}$ & $0.99(0.99-1.00)$ & 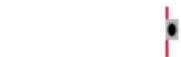 \\
\hline Tuttle $^{25}, 2015$ & $0.81(0.69-0.90)$ & - & $0.99(0.98-1.00)$ & 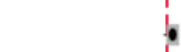 \\
\hline Yang $^{26}, 2017$ & $0.82(0.65-0.93)$ & - & $0.89(0.80-0.95)$ & $\because-$ \\
\hline Yoon $^{27}, 2017$ & $0.74(0.65-0.82)$ & | & $1.00(0.99-1.00)$ & . \\
\hline \multirow[t]{3}{*}{ Combined } & & $\phi$ & & $\phi$ \\
\hline & $0.78(0.71-0.83)$ & $\begin{array}{l}1 \\
1 \\
1 \\
1\end{array}$ & $0.99(0.98-0.99)$ & 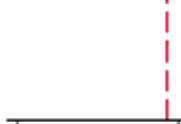 \\
\hline & & 1.0 & & 0.8 \\
\hline
\end{tabular}

\section{Figure 2}

Paired forest plots of sensitivity and specificity of the Quidel Sofia rapid influenza FIA for detection of influenza A 


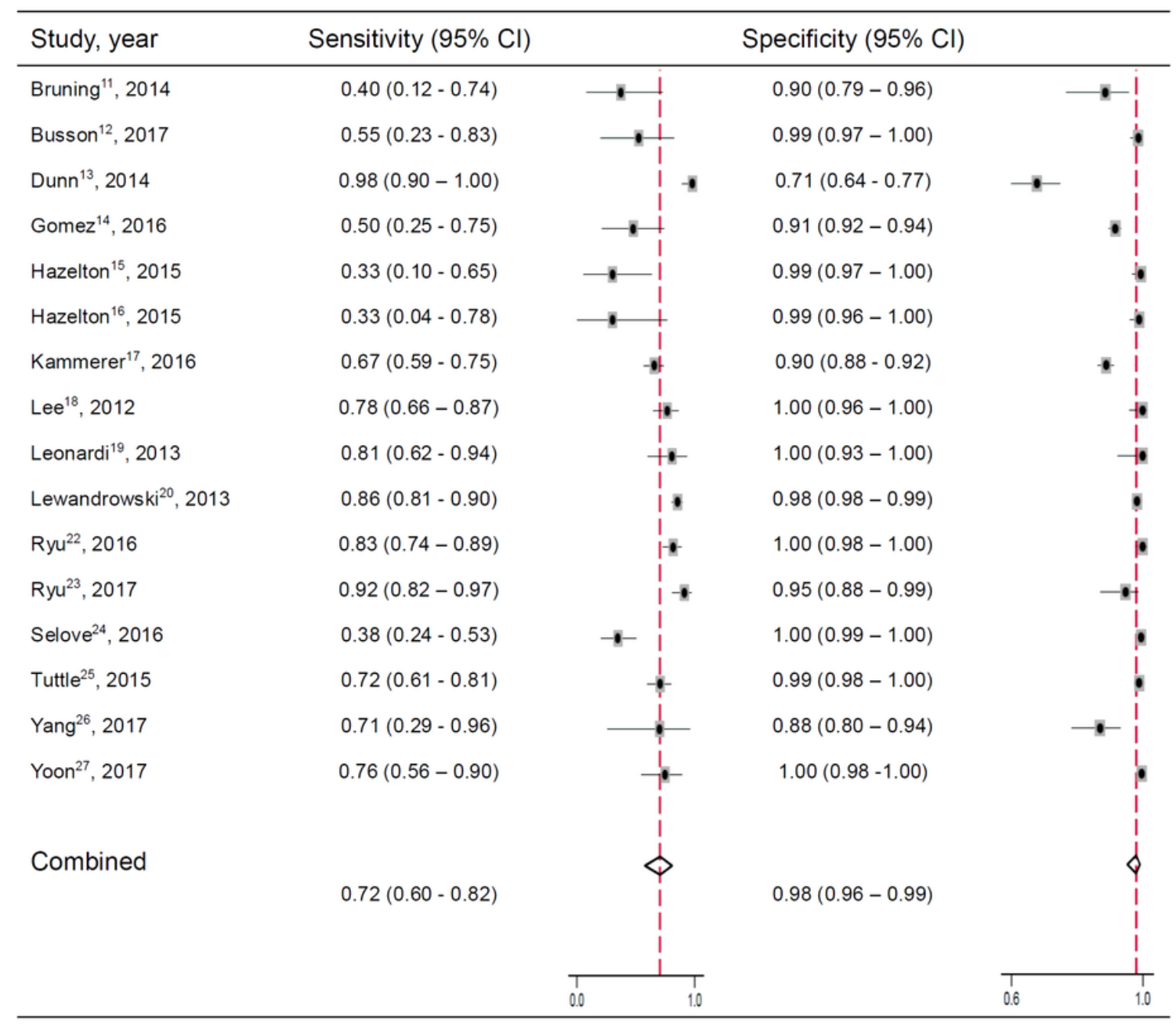

\section{Figure 3}

Paired forest plots of sensitivity and specificity of the Quidel Sofia rapid influenza FIA for detection of influenza B 

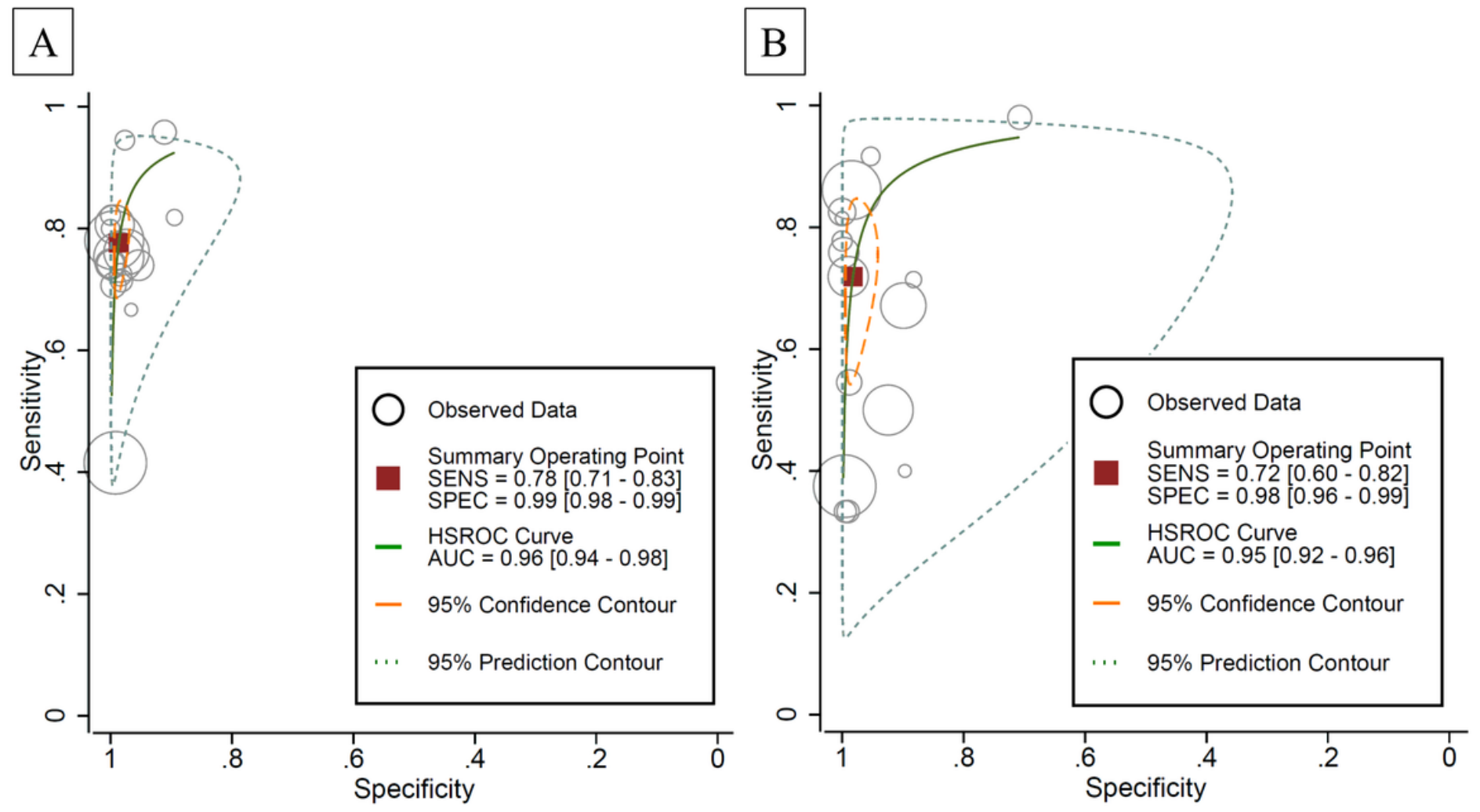

\section{Figure 4}

Hierarchical summary receiver operating characteristic curves for the Quidel Sofia rapid influenza FIA for detection of (A) influenza A and (B) influenza B 